\title{
Sugarcane expansion and farmland prices in São Paulo State, Brazil
}

\author{
Alex Wilhans Antonio Palludeto ${ }^{1}$, Tiago Santos Telles ${ }^{2^{*}}$, Roney Fraga Souza ${ }^{3}$ and Fábio Rodrigues de Moura ${ }^{4}$
}

\begin{abstract}
Background: Brazil is the world's largest sugarcane producer, and its production is concentrated in south-central and northeast regions, particularly in the state of São Paulo. The land use change, principally from the increasing sugarcane production, may reflect in the farmland prices. The aim of this study is to evaluate the extent to which agricultural land prices in São Paulo are determined by variations in cultivation and prices of three products that represent a significant share of agriculture in the state: sugarcane, soy and corn, in a low-inflation environment.
\end{abstract}

Methods: Analysis is based on data from the Rural Development Offices (EDR) from 1997 to 2013. A simple panel data model is constructed with land price as the dependent variable, subdivided, according to the definition of the São Paulo State Institute of Agricultural Economics, into first- and second-class croplands. Cultivation area, unit price of the products, and lease value are explanatory variables, according to each crop. Inflation and the overall production value of São Paulo's farming production, excluding the production values of corn, soy and sugarcane, also serve as explanatory variables.

Results: The results show that in São Paulo, although part of the land price variation can be explained by the variables associated with their productive use, the impact of inflation indicates that land's function in storing value contributes significantly to land prices.

Conclusions: The most prominent conclusion is that expansion in sugarcane cultivation has led to higher farmland prices in the state of São Paulo.

Keywords: Land use, Land value, Land price, Land profitability, Bioenergy crops, Panel data

\section{Background}

Studies of land use changes and farmland prices are very useful to policy makers, who need to be able to identify the determinants of such changes. Changes in land use patterns significantly affect both the environment (biodiversity, water pollution, soil erosion, and climate change) and economic and social welfare [9].

In Brazil, the large fluctuation in rural land prices during the periods of high inflation that extended throughout the 1970s, 1980s, and early 1990s (associated with the modernization of farming production that began in the 1960s) stimulated several studies on the Brazilian land market. The analyses by Sayad [45, 46], Oliveira

\footnotetext{
*Correspondence: telles@iapar.br

${ }^{2}$ Instituto Agronômico do Paraná, C.P. 10.030, Londrina, Paraná CEP

86057-970, Brazil

Full list of author information is available at the end of the article
}

and Costa [34], Pinheiro and Reydon [36], Rezende [43], Egler [15], and Bacha [1] are representative of this period. Although different approaches were taken, these studies are dedicated primarily to the identification of factors beyond those strictly related to farming activity that acted to determine land prices in the country. In particular, the literature began to consider the impact of macroeconomic variables on land prices.

Beginning with the arrival of the Real Plan and subsequent monetary stability in 1994, however, increased interest rates and low exchange rates in the country led to a new dynamic in the agricultural land market [58]. As noted by Reydon and Plata [41], in the years immediately following implementation of the Real Plan, there was a marked drop in agricultural land prices in the country. According to these authors, this devaluation occurred as a result of the reduced inflation rate, which diminished 
the demand for assets that serve as a store of value, such as land. They also concluded that the price drop was the result of increased interest rates, which made financial assets more attractive than land because the former began to yield better profit expectations to investors. In this context, the influence of agricultural land in storing value decreased, even if it was not completely eliminated. Hence, the authors suggest that the demand for agricultural land became more closely related to its productive dimension than to its capacity to store value, which is an economic dimension linked to speculation ${ }^{1}$ [40].

In fact, with the subsequent exchange devaluation that began in 1999, exports were favored and the prices paid for important crops such as sugarcane, corn and soy increased, followed by a rise in the price of agricultural land in the primary producing regions for these commodities $[4,30]$-among them, the state of São Paulo. ${ }^{2}$ The trend of increased demand for agricultural land for production purposes gained importance in the state of São Paulo, especially from the expansion of sugarcane farms $[13,20]$ destined for the production of biofuels and agro-energy [17]. One of the reasons for this expansion is related to the liberalization of sugar exports starting in 1990, following the intense process of trade liberalization of the Brazilian economy at the time. In 2007, the state of São Paulo was responsible for $60 \%$ of the sugarcane production in Brazil and 53\% of the total area occupied by this crop. The advancement in sugarcane farming activity is occurring mostly in areas formerly used to raise cattle, and primarily through land leasing, which maintains the market for land used for sugarcane production on the rise $[19,32,50]$. Furthermore, São Paulo has one of the most complete logistics infrastructures in the country [49], which reduces the costs of agricultural activities. Associated with the good performance of the farming sector, the demand for land certainly reflects the favorable nature of this environment, which in turn has been reflected in higher land prices since 2000 [54].

Several studies conducted in Brazil after 1995, especially those by Plata [37], Reydon and Plata [41], Gasques and Bastos [20], Zilli et al. [58], and Ferro and Castro [18], indicate that the determinants of land prices in Brazil may be connected primarily to its role as a production

\footnotetext{
${ }^{1}$ When the word speculative or associated terms are used in this study, one should consider them as a generalization for the several markets of the classic definition given by Kaldor [27], p. 1: "Speculation, for purposes of this article, may be defined as the purchase (or sale) of goods with a view to resale (or repurchase) at a later date, where the motive behind such action is the expectation of a change in the relevant price relative to the ruling price and not a gain obtained through their use, or any type of transformation performed on them or their transfer between different markets."

2 Because of the modernization of the production process, agriculture in São Paulo is considered among the most developed in the country.
}

factor, suggesting that a similar movement may have occurred in the state of São Paulo.

This study thus aims to contribute to the recent literature on land prices in Brazil by examining the determinants of agricultural land prices in the state of São Paulo using an empirical evaluation of the effects of variables associated with productive activity on land prices. The analysis is based on data from the Rural Development Offices (Escritórios de Desenvolvimento Rural-EDR) ${ }^{3}$ from 1997 to 2013. The specificity of the analysis conducted here lies precisely in the adoption of a data disaggregation level based on EDRs, in contrast to the literature on land prices for Brazil in general.

More specifically, this paper analyzes the extent to which land prices in São Paulo are determined by variations in the area of cultivation and in the prices linked to three of the products that represent a significant share of agriculture in the state: sugarcane, soy, and corn, in a low-inflation environment. An econometric model is constructed with land price, the dependent variable, subdivided, according to the definition of the Institute of Agricultural Economics (Instituto de Economia Agrícola-IEA) of the state of São Paulo, into first- and second-class croplands. Explanatory variables include the cultivation area of each of the crops considered, the unit price of their products, the land-lease value according to each crop, and the inflation rate and overall production value of São Paulo's farming production, excluding corn, soy, and sugarcane production values. The overall production value for each unit is incorporated into the model to reflect the income associated with other crops (e.g., coffee, oranges, and cattle), whose importance in the agricultural production of the state cannot be disregarded.

\section{Methods}

\section{Conceptual framework}

Land value has been a privileged subject of analysis in numerous economic studies ever since the conceptualization of a tripartite division of factors of production into land, labor, and capital [47]. In general, several theoretical approaches to the land market have considered the negotiated asset price to be a direct or indirect result of its potential earning stream $[29,51]$. That is, even considering some assumptions with respect to the overall operation of the economy and the role that land plays in it, it is possible to identify a common element with

\footnotetext{
${ }^{3}$ The EDR is a group of municipalities defined by the Institute of Agricultural Economics of the state of São Paulo that includes the Houses of Agriculture (Casas de Agricultura), which are present in all municipalities of São Paulo State.
} 
respect to land price determinants in several theoretical approaches. That common element is the fact that land price is determined by the earnings that it generates to those who make use of it. From this perspective, land value is dictated by the production capacity of the land.

The relative consensus that had been established in the literature, however, was shattered in the mid-1950s, when many empirical studies found that land prices in the USA rose well above that which would be justified by the earnings from the land use, contrary to what was suggested by the theories of the time $[10,48]$. Because of what was known as the "land price paradox" (the name given to this phenomenon in the specialized literature), various scholars began to consider factors not strictly related to land production capacity as determinants of land value. However, many of these authors restricted the influence of these other determinants to the impact they had on the agricultural sector itself. It was thus found that other factors, in addition to production-related ones, could influence land price. Studies by Scofield [48], Chryst [10] and Traill [52] provide some examples of the way land price determinants began to be considered.

Scofield [48] emphasized that land had a tendency to be more highly valued than the income growth derived from its productive use. To the author, price-sustaining policies, technological advances, and even the use of land as a store of value, e.g., as protection against increased inflation rates, changed the land price and could thus be considered among the elements determining it. Although Chryst [10] argued that land price should reflect the earnings the land is able to generate, including production increases, the author also considers non-agricultural earnings in land price formation. From this same perspective, Traill [52] found that in England, the increase in land prices in the 1960s was much higher than any increase in earnings from agricultural activities. In this context, the relation between the profitability of agricultural activities and land price was not as direct as it had been.

Other authors, such as Tweeten and Martín [53], Reinsel [38], Reinsel and Reinsel [39], Doll et al. [14], Just and Miranowski [26], and Weersink et al. [55] investigated the impact of public policy on land price. For example, Reinsel and Reinsel [39] observed that the present value of the land earnings stream, farm credit, the interest rate, and the inflation rate acted as land price determinants. Thus, the authors highlight factors associated with agricultural activities and those related to public policies in the sector. In the same vein, Doll et al. [14] performed an empirical assessment of the evolution of land price in the USA and developed a model that includes variables directly associated with agricultural activity, the interest rate, and other variables that reflect the existence of different government incentives. In general, they found that public policies directed toward the agricultural sector, especially credits and government subsidies, stimulated the demand for land, which raises its price.

Indeed, several factors are currently considered in the literature to be determinants of land prices: institutional aspects [25], spatial influence [8, 16, 23, 42, 57], international investment $[2,44]$, and the rental price of land [24, $51]$, among others factors.

The observation that in Brazil, during periods of high inflation after the modernization of Brazilian agriculture during the 1960s, land prices lost their relationship to the earnings level of agricultural activity led authors such as Sayad [45] and Telles et al. [51], among others, to argue that, in general terms, speculation, in addition to factors associated with agriculture, contributed to explanation of land value changes in the country.

Sayad [45] noted that, while serving as a store of value in periods of accelerated inflation, demand for land can exist regardless of the prevailing conditions in the production sphere. Land income was relatively constant during different economic cycles, making land a highdemand asset in periods of cyclical decline. Egler [15], in turn, draws a parallel between the land market and financial markets, noting the importance of interest rate movements as a land price determinant. To Reydon et al. [42], the determination of land value depends (in addition to the prices of agricultural products and inputs) on the actual interest rate, farming credits, and technological innovations. Reydon and Plata [41], as another example, state that between 1966 and 1975, growth in land price was influenced by technological innovation that changed the way in which agricultural activities were conducted. For Novo et al. [33], buying land and investing in farming is based on several reasons, including capital protection (land value used to increase over time and is considered a safe asset to invest money earned in urban business), social recognition (to pursue a farm is a clear sign of wealth to the urban society), leisure weekends and vacation activity, and nostalgia. Oliveira and Costa [34] also highlight that, in addition to agricultural product prices and inputs, the transportation infrastructure was one of the determining factors in land price.

In summary, land is a production factor and its price therefore reflects the income generated by the production activities it enables. However, land is also a financial asset used as a store of value, most importantly in periods of high inflation rates and uncertainties related to the economic environment. Land is also used as a guarantee for obtaining credit and government subsidies. Because of these additional financial factors, land is often used as the target of speculation [31]. Moreover, land prices reflect governmental policies, such as taxes, subsidies, 
technical assistance, and other programs that may be directly or indirectly related to agriculture. The costs and benefits of such policies are often capitalized in the land prices affected by them. As a result, land price result from a broad range of factors, which makes the task of measuring its determinants more complex.

Nevertheless, with the economic stability resulting from the Real Plan (1994) in Brazil, studies indicated that land price determinants became increasingly associated with production factors, i.e., the income obtained from agricultural activities $[6,7,18,37,41,58]$. This argument is even more relevant for the state of São Paulo, a region where a strong expansion in corn, soy, and especially sugarcane crops has occurred [13]. Thus, due to the data limitation for the selected unit of analysis, i.e., the EDRs, we opted for the use of variables associated with these cultures of the set of possible factors that may contribute to the determination of land prices.

\section{Data and descriptive statistics}

The data used in this study are presented in Table 1 . They were acquired from the IEA and from the Getúlio Vargas Foundation (Fundação Getúlio Vargas-FGV). It is important to note that all variables measured in monetary terms were deflated and are shown in constant Reais (2013 BRL). The land price is divided into firstclass croplands and second-class croplands according to the specifications of the EDR, and according to the classification established by the IEA as follows: (1) "Firstclass cropland: First-class cropland is potentially fit for annual crops, perennial crops and other uses, and supports intensive management of crop practices, tillage, etc. It is medium to high productivity land that can be mechanized, being flat or slightly sloping and with deep and well-drained soil" (IEA); (2) "Second-class cropland: Although potentially fit for annual and perennial crops and other uses, second-class cropland has more serious limitations than first-class cropland. It may have mechanization problems because of steep slopes. However, the soil is deep, well drained, fertile, while sometimes requiring some type of compost" (IEA).

Table 2 Descriptive statistics of the variables used Source: prepared by the authors based on IEA and FGV data

\begin{tabular}{|c|c|c|c|c|c|}
\hline Variables & $\begin{array}{l}\text { Observa- } \\
\text { tions }\end{array}$ & Mean & SD & $\begin{array}{l}\text { Mini- } \\
\text { mum }\end{array}$ & Maximum \\
\hline$P 1$ & 679 & $15,685.45$ & 8887.64 & 1550.87 & 63,380 \\
\hline$P 2$ & 679 & $12,665.57$ & 7426.64 & 1436.03 & 51,670 \\
\hline $\begin{array}{l}\text { Area_Sug- } \\
\text { arcane }\end{array}$ & 670 & $107,022.92$ & $107,921.65$ & 4.00 & 488,500 \\
\hline Area_Corn & 680 & $24,506.59$ & $28,170.08$ & 98.00 & 173,500 \\
\hline Area_Soy & 680 & $14,043.86$ & $30,503.19$ & 0 & 169,200 \\
\hline $\begin{array}{c}\text { Price_Sug- } \\
\text { arcane }\end{array}$ & 680 & 62.19 & 9.20 & 47.30 & 80.42 \\
\hline Price_Corn & 680 & 28.09 & 3.91 & 21.08 & 35.10 \\
\hline Price_Soy & 680 & 53.15 & 7.91 & 39.07 & 67.01 \\
\hline $\begin{array}{c}\text { Lease_Sug- } \\
\text { arcane }\end{array}$ & 591 & 772.51 & 284.65 & 248 & 3468 \\
\hline Lease_Corn & 625 & 445.70 & 149.96 & 93.89 & 1220 \\
\hline Lease_Soy & 420 & 506.65 & 161.51 & 248.44 & 1205 \\
\hline Vp_Total & 680 & $683,100^{a}$ & $342,322^{a}$ & $60,170^{a}$ & $2,236,000^{a}$ \\
\hline
\end{tabular}

a Values divided by 1000

Table 1 Information on the data used Source: prepared by the authors

\begin{tabular}{|c|c|c|c|}
\hline Model variables & Data used & Unit & Source \\
\hline$P 1$ & First-class cropland price & 2013 BRL per hectare & IEA \\
\hline$P 2$ & Second-class cropland price & 2013 BRL per hectare & IEA \\
\hline Area_Sugarcane & Sugarcane cultivation area & Hectare & IEA \\
\hline Area_Corn & Corn cultivation area & Hectare & IEA \\
\hline Area_Soy & Soy cultivation area & Hectare & IEA \\
\hline Price_Sugarcane & Sugarcane price & 2013 BRL per ton & IEA \\
\hline Price_Corn & Corn price & 2013 BRL per bag & IEA \\
\hline Price_Soy & Soy price & 2013 BRL per bag & IEA \\
\hline Lease_Sugarcane & Sugarcane leasehold & 2013 BRL per hectare per year & IEA \\
\hline Lease_Corn & Corn leasehold & 2013 BRL per hectare per year & IEA \\
\hline Lease_Soy & Soy leasehold & 2013 BRL per hectare per year & IEA \\
\hline Vp_Total & Total agricultural production value (excluding corn, soy, and sugarcane) & 2013 BRL & IEA \\
\hline IGP & IGP-DI (base = 2013) & $2013=100$ & FGV \\
\hline T2011 & Dummy for 2011 & & \\
\hline T2012 & Dummy for 2012 & & \\
\hline T2013 & Dummy for 2013 & & \\
\hline
\end{tabular}




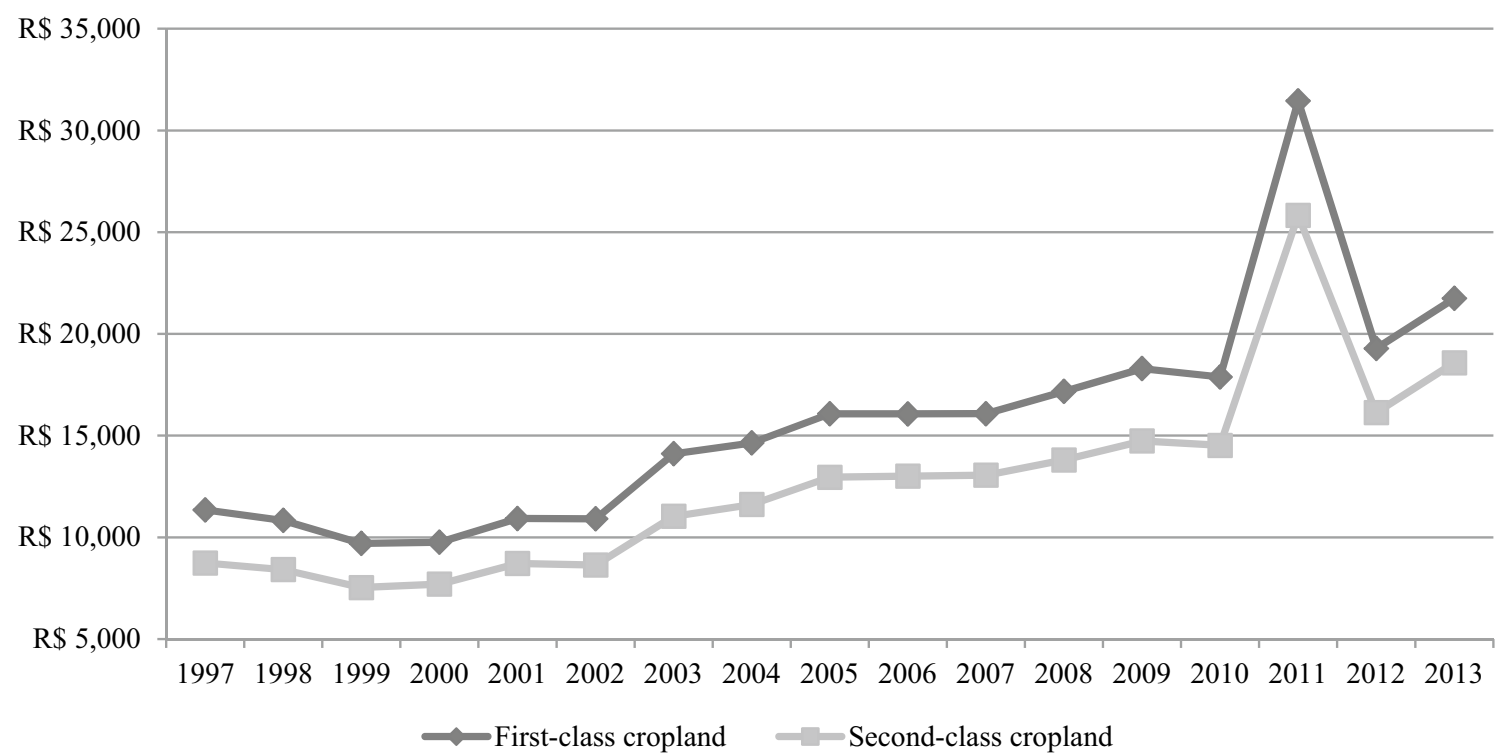

Fig. 1 Mean actual price of first- and second-class cropland in the state of São Paulo (1997-2013). Source: Prepared by the authors based on IEA data

The descriptive statistics of the variables used are shown in Table 2. It should be noted that because the data used do not have the same number of observations for all variables (Table 2), the panel described in the subsection below is unbalanced. Sugarcane, corn, and soy crops are predominant in certain regions. Therefore, variables have large ranges. As an example, the soy cultivation area (Area_Soy) has a minimum value of 0 hectares and a maximum value of 169,200 ha.

Figure 1 graphically illustrates the evolution of the mean real price of first- and second-class lands in the state of São Paulo between 1997 and 2013. Similar price behavior for both classes of land is observed over the same time period. Between 1997 and 2013, there was an increase in value of $91.64 \%$ for first-class croplands and $112.58 \%$ for second-class croplands. The data show that, between 1997 and 1999, land was devalued, a movement similar to the one previously discussed for Brazil as a whole. After 2000, an increase in the value of land began, and between 2005 and 2007 land prices stabilized. In 2008, there was a slight increase in land prices in relation to the previous period, followed by a slight decrease in 2010. In 2011, there is a large increase in land value, most likely caused by the high prices of agricultural commodities, especially sugarcane, corn, and soy, in addition to the speculative effect inherent to land price. In 2012, there was a drop in land prices, possibly resulting from the drop in commodity prices, legal insecurity (such as the acquisition of land by foreigners), and environmental impediments resulting from the new Forest Code. Finally, in 2013, prices started to rise again, regaining the upward trajectory that began in $2000{ }^{4}$

The EDR is chosen as the unit of analysis because it is the smallest unit for which reliable data are available over the period of analysis (1997-2013), which provides robustness to the model results. With respect to the explanatory variables, the crops chosen (corn, soy, and sugarcane) represent the main temporary ${ }^{5}$ agricultural activities of the state. As illustrated in Fig. 2, the share of the sum of corn, soy, and sugarcane production values in the total production value of São Paulo's farming activity increases over time, from approximately $30 \%$ in 1997 to $55 \%$ in 2013 . This movement is credited primarily to sugarcane. When considering shares of cultivated area, the importance of these three crops is also evident [13]. As displayed in Fig. 3, the share of the sum of corn, soy, and sugarcane crop areas in the total agricultural area of São Paulo, equivalent to the sum of the temporary crop

\footnotetext{
${ }^{4}$ Naturally, as this is the mean price of the EDRs in the state of São Paulo, important individual differences may remain hidden. For example, with the exception of the years after 2011, São Paulo and Campinas show a continuous drop in land price. The allocation of land in the rural areas of these EDRs may not be fully directed to agriculture and may include activities related to urban life, such as clubs, parks.

${ }^{5}$ The study's choice to analyze temporary crops reflects their importance within the state of São Paulo's farming activity, as well as the assumption that the impact of these crops on the formation of land prices is best captured by the proposed model. If considered permanent crops, it would be necessary to take into account the different temporalities of each crop as a way to get a reasonable approximation of the activity earnings, a fact that would make the model and the interpretation of its results more complex.
} 


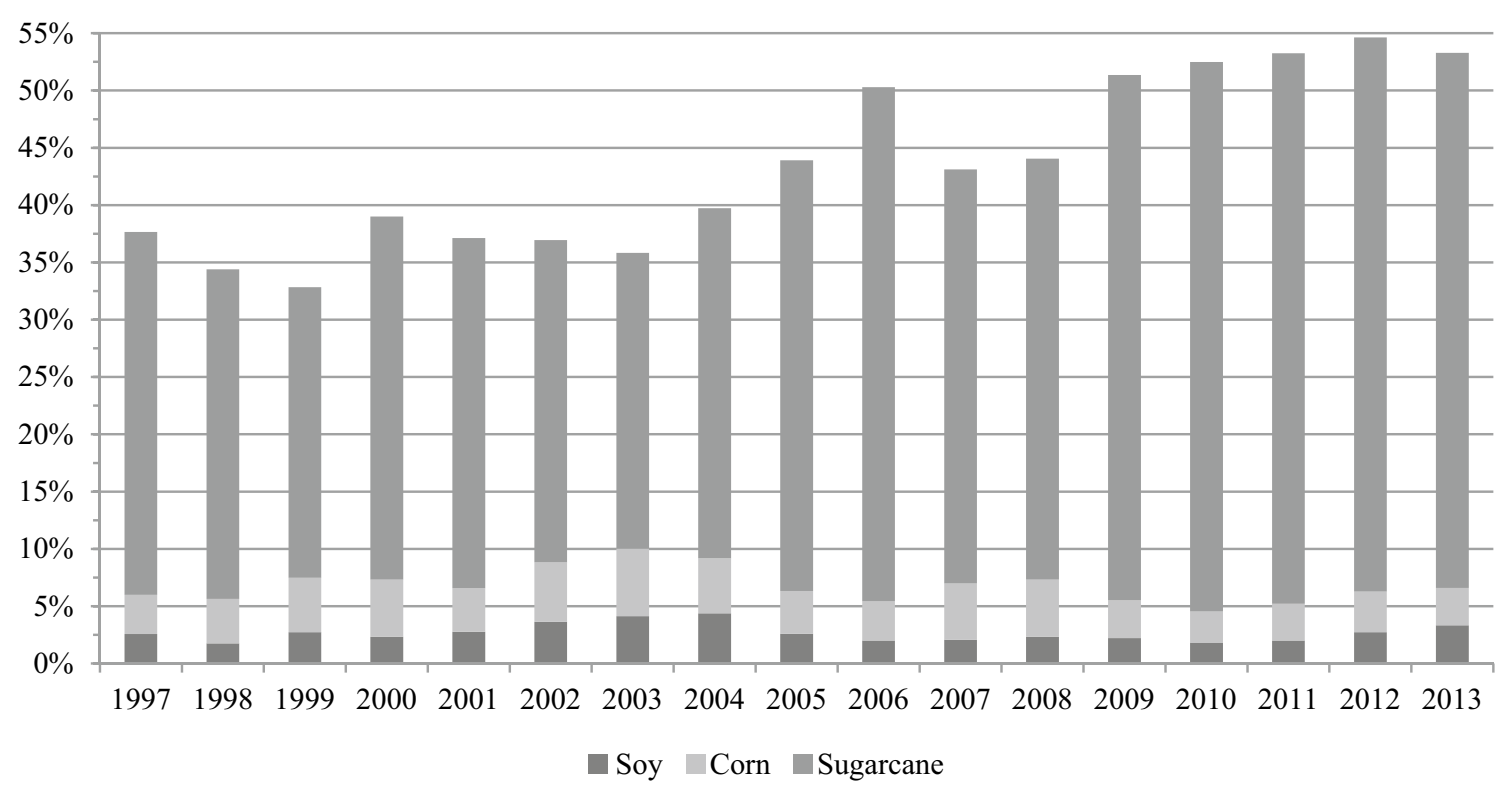

Fig. 2 Share of corn, soy, and sugarcane production values in the agricultural production value for the state of São Paulo (1997-2013). Source: Prepared by the authors based on IEA data

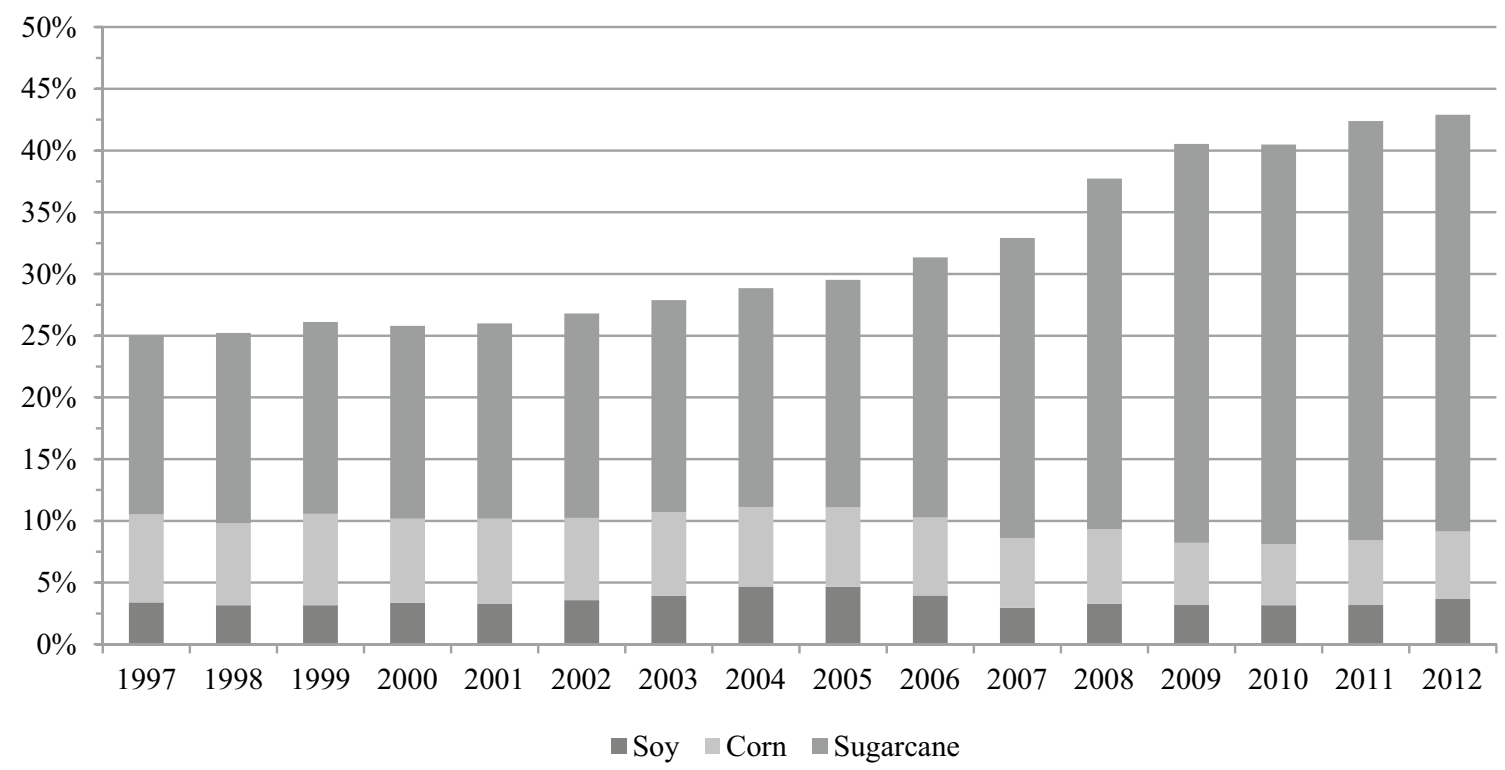

Fig. 3 Share of cultivation area dedicated to corn, soy, and sugarcane in the total agricultural area of the state of São Paulo (1997-2012). Source: Prepared by the authors based on Brazilian Institute of Geography and Statistics (Instituto Brasileiro de Geografia e Estatística (IBGE) data

areas, the permanent crop areas and pastures, increases from less than $25 \%$ in 1997 to more than $40 \%$ in 2012.

The area, the unit price, and the leasehold price of each of these three crops are variables used to assess the impact of variations in the earnings of these activities on land prices in the state of São Paulo. The inclusion of the total agricultural production value of the state of São Paulo captures the added effect of other activities.

Finally, the general price index of domestic availability [Índice Geral de Preços-Disponibilidade Interna (IGPDI)] represents the role of the land as a store of value, since the demand for land reflects the willingness of 
agents to protect their wealth, depending on the rate of inflation. Moreover, as a way to isolate the dramatic rise in land prices in 2011 (Fig. 1), dummy variables were constructed for the years 2011, 2012, and 2013.

\section{Empirical model}

This study applies panel data econometric techniques, in which time series and cross-sectional data are combined, allowing higher degrees of freedom, reducing the collinearity between explanatory variables, and controlling for unobservable heterogeneity present in the units of analysis $[21,22,56]$. In this case, the units of analysis are the EDRs in the state of São Paulo.

The empirical analysis applies the following econometric model: variance for each EDR) and first-order autocorrelations. In this analysis, tests are conducted to determine the presence of these error structures. If the results indicate the presence of heteroskedasticity between EDRs and/ or first-order autocorrelations, appropriate methods are implemented to correct the model.

\section{Model selection tests}

To determine the appropriate model for the data, the following procedures were employed: (1) the BreuschPagan Lagrangian multiplier test was applied in order to choose between a pooled ordinary least squares (pooled OLS) model, which does not present unobservable individual effects, and the random effects model I. If the null hypothesis is rejected, the random effects model is

$$
\begin{aligned}
\log P_{i t}= & \beta_{0}+\beta_{1} \log \text { Area_Sugarcane }_{i t}+\beta_{2} \log \text { Area_Corn }_{i t}+\beta_{3} \log \text { Area_Soy }_{i t} \\
& +\beta_{4} \log \text { Price_Sugarcane }_{i t}+\beta_{5} \log \text { Price_Corn }_{i t}+\beta_{6} \log \text { Price_Soy }_{i t} \\
& +\beta_{7} \log \text { Lease_Sugarcane }_{i t}+\beta_{8} \log \text { Lease_Corn }_{i t}+\beta_{9} \log \text { Lease_Soy }_{i t} \\
& +\beta_{10} \log \mathrm{Vp}_{-} \text {Total }_{i t}+\beta_{11} \log \mathrm{IGP}_{i t}+\varepsilon_{i t}
\end{aligned}
$$

where $i=1,2, \ldots, 40$, refers to each of the 40 EDRs selected, $t=1,2, \ldots, 17$, indexes years 1997-2013, $\beta_{0}$ is the intercept, $\beta_{1}$ to $\beta_{11}$ are the coefficients of the covariables defined as potential determinants of land price, $\beta_{12}$, $\beta_{13}$, and $\beta_{14}$ are the coefficients of the dummy variables for year 2011, 2012, and 2013, $\mu_{i}$ captures the unobservable individual effects of the EDRs, and $\varepsilon_{i t}$ is the idiosyncratic error term. The number of observations is not the same for all variables in the analysis, thus leaving the panel unbalanced (Table 2).

The unobserved heterogeneity of the EDRs can be addressed by means of a fixed effect, or may be treated as a random variable. If the specific effect of the units is defined as a random variable, the random effects model is used, in which $\mu_{i} \sim \operatorname{IID}\left(0, \sigma_{\mu}^{2}\right), \varepsilon_{i t} \sim \operatorname{IID}\left(0, \sigma_{\varepsilon}^{2}\right)$, with $\mu_{i}$ assumed to be independent from both the idiosyncratic error term and the independent regressors of $\mu_{i}$ and $\varepsilon_{i t}$. The fixed effects model assumes $\mu_{i}$ to be a fixed parameter in time, estimable for each unit, with $\varepsilon_{i t} \sim \operatorname{IID}\left(0, \sigma_{\varepsilon}^{2}\right)$ and the independent regressors of $\varepsilon_{i t}$. In the fixed effects model, no independence is assumed between covariables and the unobservable heterogeneity of the units. The parameters estimated using the random effects model become inconsistent if there is correlation between individual effects and covariables. In this situation, the fixed effects model should be used in order to generate consistent coefficients [3].

Data in the cross-sectional and time series format are likely to have complex error structures, such as the presence of heteroskedasticity among the units (specific used; (2) if the random effects model is favored over the pooled OLS model, the Hausman test is then applied in order to choose between the fixed effects model and the random effects model; (3) if the fixed effects model is chosen over the random effects model, an $F$ test is then used to determine whether at least one fixed effect is different from zero; (4) the hypothesis of heteroskedasticity between individuals is tested. If the null hypothesis of heteroskedasticity is rejected, the structure of the error variance-covariance matrix is corrected, incorporating the variance estimate for each EDR; and (5) the data are tested for first-order autocorrelations. If first-order autocorrelations are found to be present, the first-order autocorrelation error coefficients are estimated. Table 3 shows the results of these applied tests.

Based on the Breusch-Pagan LM test and the Hausman test, the unobserved heterogeneity of individuals is incorporated using the fixed effects model. However, the heteroskedasticity and autocorrelation tests demonstrate the existence of two non-spherical disturbances in the model. Because of this result, three different estimation methods are used to correct the error structures in the model as follows: (1) fixed effects (within) [FE AR(1)] to control for first-order autocorrelations; (2) panel-corrected standard errors (PCSE) to correct for heteroskedasticity and the autocorrelations; and (3) feasible generalized least squares (FGLS) to correct for heteroskedasticity and autocorrelations.

The FGLS method that is applied was developed by Parks [35]. It corrects the error variance-covariance 
Table 3 Tests used to identify the model Source: prepared by the authors

\begin{tabular}{|c|c|c|c|c|c|}
\hline \multirow[t]{2}{*}{ Test } & \multirow[t]{2}{*}{ Null hypothesis } & \multirow[t]{2}{*}{ Alternative hypothesis } & \multicolumn{2}{|l|}{ Test value } & \multirow[t]{2}{*}{ Conclusion } \\
\hline & & & $P 1$ & $P 2$ & \\
\hline Breusch-Pagan LM & Pooled OLS & Random effects & $\begin{array}{l}498.35 \\
p=0.000\end{array}$ & $\begin{array}{l}391.61 \\
p=0.000\end{array}$ & $\begin{array}{l}\text { OLS is rejected in favor of } \\
\text { random effects }\end{array}$ \\
\hline Hausman & Random effects & Fixed effects & $\begin{array}{l}86.29 \\
p=0.000\end{array}$ & $\begin{array}{l}108.48 \\
p=0.000\end{array}$ & $\begin{array}{l}\text { Random effects is rejected in } \\
\text { favor of fixed effects }\end{array}$ \\
\hline $\begin{array}{l}\text { F test for detection of fixed } \\
\text { effects }\end{array}$ & $\begin{array}{l}\text { All fixed effects are equal to } \\
\text { zero }\end{array}$ & $\begin{array}{l}\text { At least one fixed effect is } \\
\text { different from zero }\end{array}$ & $\begin{array}{l}68.35 \\
p=0.000\end{array}$ & $\begin{array}{l}59.99 \\
p=0.000\end{array}$ & Lack of fixed effects is rejected \\
\hline Greene for heteroskedasticity & $\begin{array}{l}\text { Same variance for each } \\
\text { individual }\end{array}$ & $\begin{array}{l}\text { The variances of individuals } \\
\text { are not equal }\end{array}$ & $\begin{array}{l}413.41 \\
p=0.000\end{array}$ & $\begin{array}{l}180.27 \\
p=0.000\end{array}$ & $\begin{array}{l}\text { Homoskedasticity is rejected } \\
\text { in favor of heteroskedastic- } \\
\text { ity among individuals }\end{array}$ \\
\hline $\begin{array}{l}\text { Wooldridge for autocorrela- } \\
\text { tion }\end{array}$ & No first-order autocorrelations & First-order autocorrelations & $\begin{array}{l}50.386 \\
p=0.000\end{array}$ & $\begin{array}{l}79.732 \\
p=0.000\end{array}$ & $\begin{array}{l}\text { Lack of first-order autocorrela- } \\
\text { tions is rejected }\end{array}$ \\
\hline
\end{tabular}

matrix structure in the presence of heteroskedasticity and first-order autocorrelations. The FGLS estimator generates asymptotically efficient coefficients and unbiased standard errors. This is considered a feasible method because the process that generates the data is not known a priori. Therefore, the variance-covariance matrix elements must be estimated. The PCSE method was developed by Beck and Katz [5], who questioned the efficiency of Parks' FGLS method in several situations commonly encountered in empirical studies. According to the authors, the FGLS method significantly underestimates the variance of parameters, thus inflating the reliability of estimates. Beck and Katz [5] developed an alternative estimator using OLS that corrects for heteroskedasticity and autocorrelations, thus generating more accurate error estimates with little or no efficiency loss when compared to FGLS. The situations under which Parks' method (1967) produces more efficient estimates, according to the Monte Carlo simulations made by Beck and Katz [5], are those with extreme heteroskedasticity or extreme contemporary correlations. In order to control for fixed effects in the FGLS and PCSE methods in the present analysis, intercept dummies are inserted for the EDRs.

It is important to emphasize that FGLS and PCSE methods, in addition to estimating the specific variance of each unit, also allow [contrary to the FE AR(1) method] the estimation of the autocorrelation parameter of disturbances for each panel unit. The FE AR(1) method estimates a single autocorrelation parameter for all units. The estimate of different parameters for the correction of the error structure generates some loss in degrees of freedom. In a panel with many units and a short temporal window, there is a critical loss of parsimony when estimating the variance and autocorrelation of each unit. Therefore, the loss of degrees of freedom may render the estimation of the entire error structure impossible. In the present study, there are 40 units of analysis and 17 time periods. In order to estimate the autocorrelation coefficient and the specific variance for each EDR, 80 degrees of freedom are lost. Adding the estimated coefficients and fixed effects dummies, there is a total loss of 130 degrees of freedom when using the FGLS and PCSE methods to correct the entire error structure as identified. Thus, given the total available observations, the estimate of all parameters for the model correction is adequately parsimonious.

\section{Results and discussion}

Primary regression results are shown in Table 4. The data demonstrate, in general, that both models fit reasonably well. Using the FE AR(1) and PCSE methods, the data show that, for first-class croplands, the percentage variation in the independent variables explains, on average, 97 and $99 \%$ of the percentage variation of land prices, respectively.

The coefficients associated with the area of sugarcane cultivation, sugarcane price, soy price, the IGP-DI, and the total production value were significant for all estimates at the $1 \%$ level, including the dummies. The coefficient of the soy cultivation area was also significant at the $1 \%$ level for both classes of land, except for the FE AR(1) method for first-class croplands, which was not significant. Sugarcane leasehold was significant at $1 \%$ only in the FGLS method, significant at $5 \%$ in the PCSE model for both classes of land, at $5 \%$ in the FE AR(1) model for second-class croplands, and at $10 \%$ in this same model for first-class croplands. The coefficient for soy leasehold was significant at the 5\% level in the FGLS model and at $10 \%$ in the PCSE model for first-class croplands. In the case of second-class croplands, the soy leasehold coefficient was significant only in the FGLS model at the $10 \%$ level.

The coefficients of the corn cultivation area, corn price, and corn leasehold were not significant for any of the methods. There is therefore no statistical evidence of the 
Table 4 Estimates of the model parameters. Source: prepared by the authors

\begin{tabular}{|c|c|c|c|c|c|c|}
\hline \multirow[t]{2}{*}{ Variables } & \multicolumn{3}{|c|}{ P1 (First-class cropland price) } & \multicolumn{3}{|c|}{ P2 (Second-class cropland price) } \\
\hline & $\operatorname{FE~AR(1)}$ & PCSE & FGLS & FE AR(1) & PCSE & FGLS \\
\hline Intercept & $0.02416(0.062)$ & $\begin{array}{l}3.4682^{* * *} \\
(1.028)\end{array}$ & $\begin{array}{l}1.97274 \\
(0.876)\end{array}$ & $\begin{array}{l}0.03615 \\
(0.060)\end{array}$ & $\begin{array}{l}3.55010 \\
(1027)\end{array}$ & $\begin{array}{l}2.0945^{* *} \\
(0.915)\end{array}$ \\
\hline Price_Sugarcane & $\begin{array}{l}0.26090^{* * *} \\
(0.067)\end{array}$ & $\begin{array}{l}0.23288^{* * *} \\
(0.062)\end{array}$ & $\begin{array}{l}0.24315^{* * *} \\
(0.052)\end{array}$ & $\begin{array}{l}0.26495^{* * *} \\
(0.066)\end{array}$ & $\begin{array}{l}0.24573^{* * *} \\
(0.065)\end{array}$ & $\begin{array}{l}0.25992^{* * *} \\
(0.055)\end{array}$ \\
\hline Price_Corn & $\begin{array}{l}0.01582 \\
(0.057)\end{array}$ & $\begin{array}{l}-0.01448 \\
(0.050)\end{array}$ & $\begin{array}{l}-0.00602 \\
(0.042)\end{array}$ & $\begin{array}{l}0.01666 \\
(0.057)\end{array}$ & $\begin{array}{l}-0.02361 \\
(0.052)\end{array}$ & $\begin{array}{l}-0.00847 \\
(0.045)\end{array}$ \\
\hline Price_Soy & $\begin{array}{l}0.22768^{* * *} \\
(0.063)\end{array}$ & $\begin{array}{l}0.2746^{* * *} \\
(0.051)\end{array}$ & $\begin{array}{l}0.27197^{* * *} \\
(0.041)\end{array}$ & $\begin{array}{l}0.22237^{* * *} \\
(0.062)\end{array}$ & $\begin{array}{l}0.28032^{* * *} \\
(0.052)\end{array}$ & $\begin{array}{l}0.27343^{* * *} \\
(0.045)\end{array}$ \\
\hline IGP & $\begin{array}{l}0.82923^{* * *} \\
(0.060)\end{array}$ & $\begin{array}{l}0.72557^{* * *} \\
(0.034)\end{array}$ & $\begin{array}{l}0.74679^{* * *} \\
(0.030)\end{array}$ & $\begin{array}{l}0.84081^{* * *} \\
(0.061)\end{array}$ & $\begin{array}{l}0.75657^{* * *} \\
(0.036)\end{array}$ & $\begin{array}{l}0.77879^{* * *} \\
(0.032)\end{array}$ \\
\hline Vp_Total & $\begin{array}{l}0.25616^{* * *} \\
(0.032)\end{array}$ & $\begin{array}{l}0.10688^{* *} \\
(0.043)\end{array}$ & $\begin{array}{l}0.16672^{* * *} \\
(0.036)\end{array}$ & $\begin{array}{l}0.25569^{* * *} \\
(0.032)\end{array}$ & $\begin{array}{l}0.10488^{* *} \\
(0.044)\end{array}$ & $\begin{array}{l}0.16977^{* * *} \\
(0.038)\end{array}$ \\
\hline Area_Sugarcane & $\begin{array}{l}0.11624^{* * *} \\
(0.028)\end{array}$ & $\begin{array}{l}0.09807^{* * * *} \\
(0.023)\end{array}$ & $\begin{array}{l}0.10064^{* * *} \\
(0.019)\end{array}$ & $\begin{array}{l}0.12252^{* * *} \\
(0.028)\end{array}$ & $\begin{array}{l}0.09338^{* * *} \\
(0.023)\end{array}$ & $\begin{array}{l}0.08439^{* * *} \\
(0.021)\end{array}$ \\
\hline Area_Corn & $\begin{array}{l}0.06761 \\
(0.042)\end{array}$ & $\begin{array}{l}-0.01166 \\
(0.033)\end{array}$ & $\begin{array}{l}0.00476 \\
(0.027)\end{array}$ & $\begin{array}{l}0.03236 \\
(0.042)\end{array}$ & $\begin{array}{l}-0.03105 \\
(0.033)\end{array}$ & $\begin{array}{l}-0.03170 \\
(0.029)\end{array}$ \\
\hline Area_Soy & $\begin{array}{l}0.02049 \\
(0.016)\end{array}$ & $\begin{array}{l}0.04422^{* * *} \\
(0.013)\end{array}$ & $\begin{array}{l}0.03608^{* * *} \\
(0.010)\end{array}$ & $\begin{array}{l}0.02058^{* * *} \\
(0.1604)\end{array}$ & $\begin{array}{l}0.04190^{* * *} \\
(0.013)\end{array}$ & $\begin{array}{l}0.042417^{* * *} \\
(0.010)\end{array}$ \\
\hline Lease_Sugarcane & $\begin{array}{l}0.07078^{*} \\
(0.039)\end{array}$ & $\begin{array}{l}0.07066^{* *} \\
(0.034)\end{array}$ & $\begin{array}{l}0.08083^{* * *} \\
(0.029)\end{array}$ & $\begin{array}{l}0.08977^{* *} \\
(0.039)\end{array}$ & $\begin{array}{l}0.07850^{* *} \\
(0.034)\end{array}$ & $\begin{array}{l}0.09110^{* * *} \\
(0.032)\end{array}$ \\
\hline Lease_Corn & $\begin{array}{l}-0.0001 \\
(0.037)\end{array}$ & $\begin{array}{l}-0.02019 \\
(0.032)\end{array}$ & $\begin{array}{l}-0.01676 \\
(0.028)\end{array}$ & $\begin{array}{l}-0.00159 \\
(0.037)\end{array}$ & $\begin{array}{l}-0.01605 \\
(0.033)\end{array}$ & $\begin{array}{l}-0.00517 \\
(0.029)\end{array}$ \\
\hline Lease_Soy & $\begin{array}{l}0.00732 \\
(0.034)\end{array}$ & $\begin{array}{l}0.04943^{*} \\
(0.029)\end{array}$ & $\begin{array}{l}0.05109^{* *} \\
(0.024)\end{array}$ & $\begin{array}{l}0.00134 \\
(0.033)\end{array}$ & $\begin{array}{l}0.04004 \\
(0.030)\end{array}$ & $\begin{array}{l}0.04582^{*} \\
(0.026)\end{array}$ \\
\hline T2011 & $\begin{array}{l}0.36371^{* * *} \\
(0.035)\end{array}$ & $\begin{array}{l}0.40579^{* * *} \\
(0.032)\end{array}$ & $\begin{array}{l}0.38605^{* * *} \\
(0.027)\end{array}$ & $\begin{array}{l}0.36712^{* * *} \\
(0.035)\end{array}$ & $\begin{array}{l}0.40801^{* * *} \\
(0.033)\end{array}$ & $\begin{array}{l}0.038111^{* * *} \\
(0.029)\end{array}$ \\
\hline T2012 & $\begin{array}{l}-0.21345^{* * *} \\
(0.041)\end{array}$ & $\begin{array}{l}-0.1937^{\text {*** }} \\
(0.034)\end{array}$ & $\begin{array}{l}-0.1948^{* * *} \\
(0.028)\end{array}$ & $\begin{array}{l}-0.1964^{* * *} \\
(0.041)\end{array}$ & $\begin{array}{l}-0.18658^{* * *} \\
(0.036)\end{array}$ & $\begin{array}{l}-0.1975^{* * *} \\
(0.031)\end{array}$ \\
\hline T2013 & $\begin{array}{l}-0.1089^{* * *} \\
(0.039)\end{array}$ & $\begin{array}{l}-0.1056^{* * *} \\
(0.032)\end{array}$ & $\begin{array}{l}-0.1005^{* *} \\
(0.026)\end{array}$ & $\begin{array}{l}-0.0780^{* * *} \\
(0.040)\end{array}$ & $\begin{array}{l}-0.07820^{* *} \\
(0.034)\end{array}$ & $\begin{array}{l}-0.0853^{* * *} \\
(0.029)\end{array}$ \\
\hline$R^{2}$ & $\begin{array}{l}W .=0.9702 \\
B .=0.0577 \\
O .=0.3478\end{array}$ & 0.9978 & - & $\begin{array}{l}W .=0.9698 \\
B .=0.0568 \\
O .=0.3800\end{array}$ & 0.9972 & - \\
\hline
\end{tabular}

W. $=R^{2}$ within. $B .=R^{2}$ between; $O .=R^{2}$ overall

*** Significant at 1\%; ** significant at 5\%; ${ }^{*}$ significant at $10 \%$. Standard errors in parentheses

effect of these variables on land price, a fact that indicates that corn cultivation may not impact land prices in the state of São Paulo.

All significant coefficients showed the expected signs. In fact, positive variations in the area of sugarcane and soy cultivation, in production values, in the leasehold value of these crops, and in the value of total agricultural production and inflation, are reflected in positive variations in first- and second-class cropland prices. An increase in the area under cultivation is associated with an increase in the demand for land that, ceteris paribus, leads to an increase in land value. An increase in the price of a certain agricultural product, with all other factors constant, causes land prices to increase by raising the production-related income. Similarly, if the landowner obtains a higher income through leasehold, the land thus provides greater earnings potential and its price therefore increases. Rising inflation results in an increased demand for land as a store of value, raising the real price of land.

Additionally, coefficients related to explanatory variables exhibit relatively similar values for both classes of land in each of the three models, indicating that land prices of first- and second-class cropland move in parallel to changes in the variables considered. For example, using the PCSE, an increase of $1 \%$ in the price per ton of sugarcane is expressed in a corresponding increase of approximately $0.23 \%$ in the first-class cropland price and $0.25 \%$ increase in the second-class cropland price. Although the variation in cultivated area exerts a relatively lesser impact on land price, the direction is similar. That is, assuming an increase of $1 \%$ in the sugarcane cultivation area, increases of approximately $0.10 \%$ in the 
first-class cropland price and $0.09 \%$ in the second-class cropland price are expected.

Particular attention should be paid to variables associated with the sugarcane industry, which were significant in all models. Coefficient levels show that the price of sugarcane, the cultivation area, and the leasehold associated with this crop are major determinants, under all three methods, of the price of the first- and second-class croplands in the state of São Paulo. ${ }^{6}$

The recent development of the biofuels sector, which is served primarily by the production of sugarcane, has been one of the most dynamic agricultural sectors in the state of São Paulo [11, 28]. Because the ethanol sector represents such an important element of agricultural production in the state of São Paulo (making the state the country's primary producer), it is noteworthy that regression analysis measured a notable effect from this sector on land prices in recent years.

On the one hand, it appears that some of the recent variation in land price has been associated with elements related to the agricultural activity itself, thus indicating that the weight of production factors in determining land price should be considered. The identification here of significant associations between production activity and land prices is supported by numerous studies of the Brazilian market, even though these studies consider different units of analysis and employ different methodologies. Dias et al. [12], in a study on land prices in Brazil between 1966 and 1998, showed that both the index of prices received and paid by producers and land productivity positively affect land price. Similarly, another depiction of the importance of the factors related to the productive use of land is found in the recent study by Ferro and Castro [18]. Considering the price of soy as one of the explanatory variables of the model for the determination of land price in Brazil from 2000 to 2010, the authors note that "land price is strongly related to income that can be obtained with this factor" [18].

However, on the other hand, the data evidence the influence of the inflation rate in determining land prices, a phenomenon primarily related to the use of land as a store of value. Even if the impact of inflation on the land market was greatly reduced in periods of relatively low and stable inflation, the evidence found in the three methods considered here suggests the contrary, i.e., that the inflation rate, among the variables in the model, has the highest

\footnotetext{
${ }^{6}$ Even if, for some methods, the coefficient of the sugarcane price is lower than that associated with soy, potentially suggesting that the price of soy has a greater influence on land price, the linear restriction test indicated that, for each type of land, the impact of the sugarcane and soy prices on land price can be considered equal. A similar relation was not found with respect to the other variables.
}

influence on land price. As shown in Table 3, a variation of $1 \%$ in the IGP-DI is reflected in a variation of, at least, $0.73 \%$ in prices for both classes of land. Therefore, one cannot discard the suggestion of several authors, such as [45] and [51], who assigned an important weight to the function of land as a store of value and identified speculation as a key determinant of land prices in Brazil. The rise in inflation, while signaling an environment of greater instability for holders of wealth, nonetheless, increases the demand for assets that serve as stores of value, land being among them. Therefore, the real land price increases through the increased profitability associated with its productive use, and also through the demand of those who see land as an asset with valuation prospects that allow them to protect their wealth from inflation.

Model results indicate that land prices in recent years in the state of São Paulo are determined by a combination of production factors and other variables not inherent to the production process, such as inflation. In fact, as demonstrated, inflation has a greater impact on land price than do the production factors. To more accurately assess the extent to which the demand for land is derived from production factors and from factors associated with speculation would require consideration of a large set of variables. However, for the level of disaggregation considered herein, i.e., EDRs of the state of São Paulo, incorporating variables that express the speculative behavior of agents, in addition to inflation, is a difficult task to perform. This undertaking awaits further analysis.

The empirical evaluation of the determinants of land prices in the state of São Paulo indicates that the variables associated with income from agricultural activity, particularly sugarcane and soy, contribute to the changes in land prices. However, even in the recent period of low and relatively stable inflation, land prices respond to factors indirectly related to its productive use. Strong evidence for the weight of inflation in the determination of land prices and for the importance of land as a store of value is found in the data.

The results suggest that land prices in the state of São Paulo are determined by a combination of production factors and factors linked to the function of land as a store of value, with greater influence of the latter, as demonstrated by the notable impact of inflation. The novelty of the simple model presented here results from the adoption of a panel data approach for EDRs. As evidenced by the significance of results presented here, it would be of interest to see further studies that employ data with this level of disaggregation. However, a better understanding of how these factors influence land use patterns over time and space would help policy makers in evaluating existing practices or in drawing up new sustainable environmentally policies. 


\section{Authors' contributions}

All authors contributed equally to this study. AWAP and TST contributed to study conception. AWAP, TST, RFS, and FRM helped in study design. AWP and TST contributed to acquisition of data. RFS and FRM contributed to analytical methods and performed modeling and data processing. AWP, TST, and RFS analyzed and interpreted the data. AWP and TST drafted the manuscript. AWP, TST, and RFS helped in critical revision. All authors read and approved the final manuscript.

\section{Author details}

${ }^{1}$ Instituto de Economia, Universidade Estadual de Campinas, Rua Pitágoras 353, Campinas, São Paulo CEP 13083-857, Brazil. ${ }^{2}$ Instituto Agronômico do Paraná, C.P. 10.030, Londrina, Paraná CEP 86057-970, Brazil. ${ }^{3}$ Faculdade de Economia, Universidade Federal de Mato Grosso, Avenida Fernando Corrêa 2367 Cuiabá, Mato Grosso CEP 78060-900, Brazil. ${ }^{4}$ Departamento de Economia, Universidade Federal da Grande Dourados, C.P. 364, Dourados, Mato Grosso do Sul CEP 79.804-970, Brazil.

\section{Competing interests}

The authors declare that they have no competing interests.

\section{Availability of data and materials}

The datasets generated and analyzed during the current study are available in the Institute of Agricultural Economics (IEA), within the São Paulo's Agency for Agribusiness Technology (APTA) repository, available in: http://www.iea.sp.gov. br/out/bancodedados.html.

\section{Consent for publication}

Not applicable.

\section{Ethics approval and consent to participate}

Not applicable.

\section{Funding}

This study was financially supported by the Universidade Estadual de Campinas (UNICAMP).

\section{Publisher's Note}

Springer Nature remains neutral with regard to jurisdictional claims in published maps and institutional affiliations.

Received: 23 September 2017 Accepted: 10 October 2017 Published online: 21 January 2018

\section{References}

1. Bacha CJC. A determinação do preço de venda e de aluguel da terra na agricultura. Estud Econ. 1989;19:443-56.

2. Baker TG, Boehlje MD, Langemeier MR. Farmland: Is it currently priced as an attractive investment? Am J Agric Econ. 2014;96:1321-33.

3. Baltagi B. Econometric analysis of panel data. 3rd ed. Chichester: Wiley; 2005

4. Barretto AGOP, Berndes G, Sparovek G, Wirsenius S. Agricultural intensification in Brazil and its effects on land-use patterns: an analysis of the 1975-2006 period. Global Change Biol. 2013;19:1804-15.

5. Beck N, Katz J. What to do (and not to do) with time series cross-section data. Am Polit Sci Rev. 1995;89:634-47.

6. Camargo AMMP, Camargo FP, Siqueira ACN, Camargo Filho WP, Francisco VLFS. Agricultural land valorization according to regional use of soil in the state of São Paulo. Inf Econ. 2004;34:28-40.

7. Camargo FP. Análise do mercado de terras agrícolas nas regiões do estado de São Paulo, 1995 a 2006. Inf Econ. 2007;37:50-63.

8. Cavailhès J, Thomas I. Are agricultural and developable land prices governed by the same spatial rules? The case of Belgium. Can J Agric Econ. 2013;61:439-63.

9. Chakir R, Le Gallo J. Predicting land use allocation in France: a spatial panel data analysis. Ecol Econ. 2013;92:114-25.

10. Chryst WE. Land values and agricultural income: A paradox? J Farm Econ. 1965;47:1265-73.
11. Deuss A. The economic growth impacts of sugar cane expansion in Brazil: an inter-regional analysis. J Agric Econ. 2012;63:528-51.

12. Dias GLS, Vieira CA, Amaral CM. Comportamento do mercado de terras no Brasil. 1st ed. Santiago: CEPAL; 2001.

13. Dias LCP, Pimenta FM, Santos AB, Costa MH, Ladle RJ. Patterns of land use, extensification, and intensification of Brazilian agriculture. Global Change Biol. 2016;22:2887-903.

14. Doll JP, Widdows R, Velde PD. The value of agricultural land in the United States: a report on research. Agric Econ Res. 1983;35:39-44.

15. Egler CAG. Preço da terra, taxa de juro e acumulação financeira no Brasil. Rev Econ Polit. 1985;5:112-35.

16. Eagle AJ, Eagle DE, Stobbe TE, van Kooten GC. Farmland protection and agricultural land values at the urban-rural Fringe: British Columbia's agricultural land reserve. Am J Agric Econ. 2015;97:282-98.

17. Ferreira Filho JBS, Horridge M. Ethanol expansion and indirect land use change in Brazil. Land Use Policy. 2014;36:595-604.

18. Ferro $A B$, Castro ER. Determinantes dos preços de terras no Brasil: uma análise de região de fronteira agrícola e áreas tradicionais. Rev Econ Soc Rural. 2013;51:591-609.

19. Ficarelli TRA, Ribeiro H. Dinâmica do arrendamento de terras para o setor sucroalcooleiro: Estudo de casos no estado de São Paulo. Inf Econ. 2010;40:44-54.

20. Gasques JG, Bastos ET. Terra: preços no Brasil. Agroanalysis. 2008;28:14-5.

21. Greene WH. Econometric analysis. 6th ed. Prentice Hall: Pearson; 2008.

22. Gujarati DN, Porter D. Basic econometrics. 5th ed. Irwin: McGraw-Hill; 2009.

23. Hausman C. Biofuels and land use change: sugarcane and soybean acreage response in Brazil. Environ Resour Econ. 2012;51:163-87.

24. Hennig S, Breustedt G, Latacz-Lohmann U. The impact of payment entitlements on arable land prices and rental rates in Schleswig-Holstein. Ger J Agric Econ. 2014;63:219-39.

25. Hüttel S, Wildermann L, Croonenbroeck C. How do institutional market players matter in farmland pricing? Land Use Policy. 2016;59:154-67.

26. Just RE, Miranowski JA. Understanding farmland price changes. Am J Agric Econ. 1993;75:156-68.

27. Kaldor N. Speculation and economic stability. Rev Econ Stud. 1939;7:1-27.

28. Kohlhepp G. Análise da situação da produção de etanol e biodiesel no Brasil. Estud Av. 2010;24:223-53.

29. Larsen HC. Relationship of land values to warranted values, 1910-48. J Farm Econ. 1948;30:579-88.

30. Lima Filho RR, Aguiar GAM, Torres Junior AM. Mercado de terras: preços em alta, liquidez em baixa. Agroanalysis. 2013;33:19-22.

31. Magnan A, Sunley S. Farmland investment and financialization in Saskatchewan, 2003-2014: an empirical analysis of farmland transactions. J Rural Stud. 2017;49:92-103.

32. Novo AL, Jansen $K$, Slingerland M, Giller K. Biofuel, dairy production and beef in Brazil: competing claims on land use in São Paulo State. J Peasant Stud. 2010;37:769-92

33. Novo A, Jansen $K$, Slingerland M. The sugarcane-biofuel expansion and dairy farmers' responses in Brazil. J Rural Stud. 2012;28:640-9.

34. Oliveira JT, Costa IDN. Evolução recente do preço de terra no Brasil: 1966-74. Rev Econ Rural. 1977;15:259-76.

35. Parks R. Efficient estimation of a system of regression equations when disturbances are both serially and contemporaneously correlated. J Am Stat Assoc. 1967:62:500-9.

36. Pinheiro FA, Reydon BP. O preço da terra e a questão agrária: algumas evidências empíricas relevantes. Rev Econ Rural. 1981;19:5-15.

37. Plata LEA. Dinâmica do preço da terra rural no Brasil: Uma análise de cointegração. In: Reydon BP, Cornélio FNM, editors. Mercados de terras no Brasil: estrutura e dinâmica. Brasília: NEAD; 2006. p. 125-54.

38. Reinsel RD. Effect of seller financing on land prices. Agric Financ Rev. 1972:33:32-5.

39. Reinsel RD, Reinsel El. The economics of asset values and current income in farming. Am J Agric Econ. 1979;61:1093-7.

40. Reydon BP, Fernandes VB, Telles TS. Land tenure in Brazil: the question of regulation and governance. Land Use Policy. 2015:42:509-16.

41. Reydon BP, Plata LEA. O plano real e o mercado de terras no Brasil: lições para a democratização do acesso à terra. In: Reydon BP, Cornélio FNM, editors. Mercados de terras no Brasil: estrutura e dinâmica. Brasília: NEAD; 2006. p. 267-84. 
42. Reydon BP, Plata LEA, Sparovek G, Goldszmidt RGB, Telles TS. Determination and forecast of agricultural land prices. Nova Econ. 2014;24:389-408.

43. Rezende GC. Política agrícola, preço da terra e estrutura agrária. Rev Econ Rural. 1982;20:73-100.

44. Sauer S, Pereira Leite S. Agrarian structure, foreign investment in land, and land prices in Brazil. J Peasant Stud. 2012;39:873-98.

45. Sayad J. Preço da terra e mercados financeiros. Pesqui Planej Econ. 1977;7:623-62.

46. Sayad J. Especulação em terras rurais, efeitos sobre a produção agrícola e o novo ITR. Pesqui Planej Econ. 1982;12:87-108.

47. Schultz TW. A framework for land economics: the long view. J Farm Econ. 1951;33:204-15.

48. Scofield WH. Prevailing land market forces. J Farm Econ. 1957;39:1500-10.

49. Sousa AF. Terra gera alta rentabilidade. Agroanalysis. 2009;29:18-9.

50. Sparovek G, Barretto A, Berndes G, Martins S, Maule R. Environmental, land-use and economic implications of Brazilian sugarcane expansion 1996-2006. Mitig Adapt Strat Global. 2009;14:285-98.

51. Telles TS, Palludeto AWA, Reydon BP. Price movement in the Brazilian land market (1994-2010): an analysis in the light of post-Keynesian theory. Rev Econ Polit. 2016:36:109-29.
52. Traill B. An empirical model of the U.K. land market and the impact of price policy on land values and rents. Eur Rev Agric Econ. 1979;6:209-32.

53. Tweeten LG, Martin JE. A methodology for predicting U.S. farm real estate price variation. J Farm Econ. 1966;48:378-93.

54. Visser O. Running out of farmland? Investment discourses, unstable land values and the sluggishness of asset making. Agric Hum Values. 2017:34:185-98.

55. Weersink A, Clark S, Turvey CG, Sarker R. The effect of agricultural policy on farmland values. Land Econ. 1999;75:425-39.

56. Wooldridge JM. Econometric analysis of cross section and panel data. 1st ed. Cambridge: MIT Press; 2002

57. Zhang W, Nickerson CJ. Housing market bust and farmland values: Identifying the changing influence of proximity to urban centers. Land Econ. 2015;91:605-26.

58. Zilli JB, Barros GSC, Bogoni NM. Precificação de terras de propriedades rurais em Cascavel-PR: Uma análise das opções reais. Teor Evid Econ. 2012;18:34-60.

\section{Submit your next manuscript to BioMed Central and we will help you at every step:}

- We accept pre-submission inquiries

- Our selector tool helps you to find the most relevant journal

- We provide round the clock customer support

- Convenient online submission

- Thorough peer review

- Inclusion in PubMed and all major indexing services

- Maximum visibility for your research

Submit your manuscript at www.biomedcentral.com/submit 